\title{
Наталія Бондар
}

\section{Недільський, Анатолій. Триста двадиять дев'ять рідкісних стародруків краєзнавчої бібліотеки Анатолія Недільського (Львів: Ліга-Прес, 2017), 100 с., іл.}

2017-й рік ознаменовано виходом в Україні трьох каталогів переважно кириличних стародруків. Прикметно, що всі три не $\epsilon$ «академічними» ані за характером описаних колекцій, ані за місцем роботи укладачів, ані за структурою опису, оскільки вони охоплюють не традиційні бібліотечні чи музейні фонди, а приватні або монастирські збірки. До таких каталогів належить і опис власної колекції директором львівської книгарні «Рідкісна книга» Анатолієм Недільським, опублікований невеликим накладом у 100 примірників. Варто додати, що ця книжка вирізняється ошатним оформленням, має тверду обкладинку та містить велику кількість якісних кольорових ілюстрацій, які візуально доповнюють бібліографічний опис.

Каталог складається з короткої передмови «Від упорядника», тобто самого власника колекції. Власне каталожна частина містить 326 позицій бібліографічного опису та 55 сторінок ілюстрацій; книжку доповнює список наукових джерел з 222 позицій та іменний покажчик. Каталог та покажчик організовано за хронологічним принципом. На жаль, брак додатків з переліком стародруків за абеткою назв, місць видання й друкарень не дозволяє без спеціальних зусиль скласти цілісне уявлення про зміст і склад збірки.

У колекції зафіксовано безперечно раритетні давні пам'ятки кириличного друку, опубліковані у Бухаресті, Вільнюсі, Києві, Львові, Могильові, Москві, Санкт-Петербурзі, Стрятині, Уневі, 
Чернігові. Рідкісними, зокрема, є 35 алігатів у складі конволюта друкарні чернігівського Троїцько-Іллінського монастиря з акцидентних (аркушевих) видань документів розпорядчого характеру - імператорських указів, інструкцій, реєстрів. Представлено в каталозі й польськомовні видання різних друкарень, переважно львівських (Св. Трійці, єзуїтського колегіуму, Івана Филиповича, Яна Шліхтина), а також тих, що діяли у Перемишлі, Почаєві та Бердичеві.

Бібліографічні описи стародруків демонструють зацікавленість автора в ідентифікації книжок, володіння навичками атрибуції дефектних примірників без вихідних відомостей, знання фахових публікацій, необхідних для опису стародруків. Попри це, описи, на жаль, не можна вважати вповні якісними. Зокрема, не всі 3-поміж них супроводжуються посиланнями на базові зведені каталоги (для українських видань це насамперед каталог Я.П. Запаска та Я.Д. Ісаєвича ${ }^{1}$, для білоруських — каталог Г. Я. Голенченка ${ }^{2}$ та ін.). Приміром, відсутність згадки про два унівські видання Псалтирів (№ 17,18$)$ у каталозі Запаска-Ісаєвича ставить під сумнів їх існування, отже, наводить на думку про можливу невірну атрибуцію описаних примірників. Незрозумілим є також опис Псалтиря львівського друку 1692-1693 рр. (№ 19). Ризиковано виглядає й атрибуція московського Октоїха 1708 р. без титульного аркуша (№ 25), адже це видання досі відоме тільки в бібліографії. Так само викликає сумнів датування 1739-м роком мініатюрного Полуустава Львівського братства (№ 72) без вихідних відомостей — на основі Пасхалії, розпочатої в 1740 p.

Предметом бібліографічної дискусії фахівців уже став опис фрагмента Полуустава (№ 23). На думку укладача, його було надруковано у Єв'є або в Кутейні, однак не зазначено, за якими критеріями визначалися саме ці два місця видання, а не, скажімо, Вільно, Київ чи Могильов, де вживали ті самі приладдя для друку - шрифти, заставки, ініціали, ілюстрації.

1 Якип Запаско, Ярослав Ісаєвич, Пам'ятки книжкового мистеитва: каталог стародруків, виданих на Украӥні: 1574-1800, кн. 1 (1574-1700) (Львів: Вища школа, 1981.); кн. 2, ч. 1 (1701-1764) (Львів: Вища школа, 1984.); кн. 2, ч. 2 (1765-1800) (Львів: Вища школа, 1984).

${ }^{2}$ Георгій Галенчанка та ін., Кніга Бєларусі: 1517-1917: зводны каталог (Мінск: Беларус. савецк. энц. імя Петруся Броуки, 1986). 
Часто використане в бібліографічних описах формулювання «в книгосховищах не знайдено», з одного боку, нібито свідчить про рідкісність описаних примірників, але з другого - ставить питання, чи дійсно у приватній збірці Анатолія Недільського зібрано таку значну кількість унікальних книг. Як правило, однозначно описати примірник, у якому бракує титульного аркуша з вихідними відомостями, можна тільки після звірки цього примірника з іншим, повним, або de visu, або шляхом звірки копій, або за наявності супутніх доказових аргументів. Якщо ж цього зробити неможливо, бібліографічний опис надежить подавати бодай у квадратних дужках, бажано зі знаком запитання або з відповідним коментарем.

В обговорюваній публікації за доказ рідкісності книжки часто слугує посилання на каталоги російських книжкових зібрань А. С. Зернової XVI-XVII ст. ${ }^{3}$ та О.О. Гусєвої XVIII ст. ${ }^{4}$ Проте обидві укладачки фіксували лише примірники російських збірок, натомість до зарубіжних, серед іншого й українських, зверталися тільки у випадку їх унікальних особливостей. Тому вказівка на те, що в каталогах Зернової чи Гусєвої стародрук фіксується лише в російських бібліотеках, а в Україні його не виявлено, втрачає сенс.

Серед інших фахових похибок упорядника згадаю опис уривка, доплетеного до Псалтиря (№ 12). Тут його датовано не пізніше 1652 р. та подано під назвою «Чин и устав обручению и венчанию». Однак упродовж XVII-XVIII ст. таке видання не друкувалося, відповідний чин входив до Требників, та й поаркушний опис примірника (арк. 226-237, 239, 240-254) свідчить про те, що він не був самостійним виданням. Відтак, опис під назвою окремого чину тільки сприятиме подальшій бібліографічній плутанині.

Часто коментарі упорядника видаються незрозумілими. Наприклад, читаємо, що примірник «Благодарственного моления» (Москва, 1797) (№ 201) відрізняється від шести подібних, зафіксованих Гусєвою, проте відмінності не деталізовано (скажімо, в датуванні, характері набору, прізвищах торедорщиків). Можна згадати й неточності в дефініціях, нечітку або недостатньо обгрунтовану

${ }^{3}$ Антонина Зернова, Книги кирилловской печати, изданные в Москве в XVI-XVII веках: Сводный каталог (Москва, 1958).

${ }^{4}$ Александра Гусева, Свод русских книг кирилловской печати XVIII века типографий Москвы и Санкт-Петербурга и универсальная методика их идентификации (Москва: Индрик, 2010). 
аргументацію щодо місця та часу друку, друкарні, назви видання, зокрема для неповних примірників без вихідних даних. Цих вад можна було б уникнути, якби каталог мав атрибути наукового видання, передусім наукового редактора та рецензентів.

Утім, попри зауважені недоліки, вихід у світ каталога приватної збірки є позитивним явищем і як факт оприлюднення для широкого загалу цінної наповненої рідкісними книжковими пам’ятками приватної збірки, і як доказ «європейськості» легального колекціонування стародруків в Україні. Це засвідчує зорієнтованість вітчизняного бібліофільства на світові традиції відкритості та інформаційної доступності для науковців і широкого загалу, а разом з тим працює на витіснення «чорного ринку» стародруків та залучає до бібліографування і дослідження стародруків колекціонерів та книгопродавців, тобто перетворює приватне колекціонування на важливий чинник розвитку вітчизняної книжкової культури.

\section{Bibliography}

Halenchanka, Heorhii Yakovich, and others, ed. Kniga Bielarusi: 1517-1917: zvodny kataloh. Minsk: Belarus. savetsk. ents. imia Petrusia Brouky, 1986.

Husieva, Alieksandra. Svod russkikh knig kirillovskoi piechati XVIII vieka tipografii Moskvy i Sankt-Pietierburga i univiersalnaia mietodika ikh idientifikatsii. Moskva: Indryk, 2010.

Zapasko, Yakym, and Isaievych, Yaroslav. Pamiatky knyzhkovoho mystetstva: kataloh starodrukiv, vydanykh na Ukraini: 1574-1800. Book. 1 (1574-1700). Lviv: Vyshcha shkola, 1981; book 2, part 1 (1701-1764). Lviv: Vyshcha shkola, 1984; book 2, part 2 (1765-1800). Lviv: Vyshcha shkola, 1984.

Ziernova, Antonina. Knigi kirillovskoi pechati, izdannyie v Moskvie v XVI-XVII viekakh: Svodnyi katalog. Moskva, 1958. 